\title{
Peningkatan Keterampilan Pemecahan Masalah melalui Model Pembelajaran Think Talk Write Peserta Didik Kelas V Sekolah Dasar
}

\section{Septian Putra Utama}

Universitas Sebelas Maret

septianpu@gmail.com

\section{Article History}

received 30/4/2021

\begin{abstract}
This study aimed to describe the improvement of data interpretation problem solving skills through the Think Talk Write (TTW) learning model. Classroom Action Research was carried out in three cycles. In one cycle through four stages, namely planning, action, observation, and reflection. Research subjects were a teacher and thirteen students. Using interviews, observations, tests, and documentation as data collection techniques. The technical data validity test uses triangulation techniques and source triagulation. The results showed that classical completeness increased in each cycle. In the pre-action by $30.77 \%$, then after the action by applying the TTW model it became $46.15 \%$ in the first cycle, increased to $69.23 \%$ in the second cycle and increased to $84.23 \%$ in the third cycle. Improvement is also seen in the average of each aspect obtained. The conclusion is that there is an increase in data interpretation problem solving skills through the Think Talk Write (TTW) learning model in class V SD N Geneng I Sukoharjo academic year 2020/2021.
\end{abstract}

Keywords: problem solving skills, mathematic learning, Think Talk Write (TTW), elementary school

\section{Abstrak}

Penelitian ini bertujuan mendiskripsikan peningkatan keterampilan pemecahan masalah interpretasi data melalui model pembelajaran Think Talk Write (TTW). Penelitian Tindakan Kelas dilaksanakan dalam tiga siklus. Dalam satu siklus melalui empat tahapan yaitu perencanaan, tindakan, observasi, dan refleksi. Subjek penelitian adalah satu guru dan tigabelaspeserta didik. Menggunakan wawancara, observasi, tes, dan dokumentasi sebagai teknik pengumpulan data. Teknis uji validitas data menggunakan triangulasi teknik dan triagulasi sumber. Hasil penelitian menunjukkan bahwa ketuntasan klasikal meningkat pada setiap siklusnya. Pada pra tindakan sebesar $30,77 \%$, kemudian setelah tindakan dengan menerapkan model TTW menjadi $46,15 \%$ pada siklus I, meningkat menjadi $69,23 \%$ pada siklus II dan meningkat menjadi $84,23 \%$ pada siklus III. Peningkatan juga terlihat pada rata-rata setiap aspek yang diperoleh. Simpulan bahwa terjadi peningkatan keterampilan pemecahan masalah interpretasi data melalui model pembelajaran Think Talk Write (TTW) pada peserta didik kelas V SD N Geneng I Sukoharjo tahun ajaran 2020/2021.

Kata kunci: keterampilan pemecahan masalah, pembelajaran matematika, Think Talk Write (TTW), sekolah dasar 


\section{PENDAHULUAN.}

Pembelajaran matematika merupakan salah satu kompetensi yang harus dimilik guru. Pembelajaran matematika bertujuan untuk mencapaian pemahaman konsep matematika (Surya et al., 2018). Pembelajaran matematika merupakan ilmu deduktif yang bertumpu pada kesepakatan dalam mengoperasikan kaidah-kaidah logika serta memiliki pola keteraturan. Menurut standar, matematika lebih dari sekedar konsep dan keterampilan untuk menguasai namun juga mencakup cara menyelidiki, bertukar pikiran, dan berkomunikasi (Kallick \& Brewer, 1997). Keterampilan pemecahan masalah matematika merupakan salah satu penguasaan logika yang harus dimiliki peserta didik. Keterampilan pemecahan masalah adalah kepandaian menggunakan pengetahuan yang dimiliki individu untuk proses intekletual dan mental menghadapi situasi baru dengan merumuskan hubungan antar fakta berdasarkan data dan informasi yang didapat, mengindentifikasi/menginterpretasikan tujuan, mencari strategi yang sesuai, menerapkan prosedur sesuai langkah-langkah secara runtut yang memungkinkan mendapat solusi (Kallick \& Brewer, 1997; Sanjaya, 2008; Sukmadinata \& Syaodih, 2012). Di era abad 21, keterampilan pemecahkan masalah sangat berguna untuk peserta didik yaitu untuk menguasai pengetahuan tingkat dunia dan berkontribusi kepada pembangunan masyarakat yang modern dan progresif serta berkelanjutan. Peserta didik yang pandai dalam keterampilan memecahan masalah akan lebih cepat beradaptasi dalam laju perubahan zaman, mereka menggunakan pengetahuan dan kemampuan yang lebih baik serta pada umumnya berprestasi tinggi (Stevens, 1997). Keterampilan tersebut diharapkan dapat memecahkan masalah yang dihadapi peserta didik dalam kehidupan sehari-hari. Kendala pemebelajaran matematika yang dihadapi peserta didik adalah soal cerita. Soal cerita matematika merupakan soal matematika yang berkaitan erat dengan kehidupan sehari-hari yang diungkapkan dengan kata-kata atau kalimat yang di dalamnya terdapat unsur pembangun narasi, seperti: tokoh; tema; serta latar kejadian (Winarni \& Harmini, 2015). Karakter soal cerita sebagai teks serta pemakaian bahasa yang khas merupakan faktor kunci kegagalan pemahaman peserta didik (Sumawarni, 2014). Sehingga, diperlukan cara untuk meningkatakan pemahaman kata yang khas dalam soal matematika.

Hasil wawancara pada 01 Maret 2021 dan hasil tes pratindakan pada 09 Februari 2021 di kelas V SD N Geneng I Sukoharjo diperoleh informasi bahwa keterampilan pemecahan masalah peserta didik masih rendah. peserta didik kesulitan dalam memahami informasi yang ada dalam teks bacaan serta penggunaan pola keteraturan pada soal cerita matematika membuat peserta didik mengalami kesulian karena kurangnya pemahaman cara pengerjaan. Hasil tes pratindakan pemecahan masalah juga menunjukan sebanyak $60,23 \%$ atau 8 peserta didik dikatakan belum tuntas. Berdasarkan hasil di atas diperlukan cara peningkatan pemahaman kata yang khas dalam soal matematika dan pembelajaran interaktif.

Redahnya keterampilan pemecahan masalah peserta didik perlu segera diatasi. Model TTW telah berhasil meningkatkan keterampilan menulis puisi pada penelitian Rahmawati (Rahmawati, 2016). Pemecahan masalah menjadi topik penelitian Monica dengan persentase ketuntasan klasikal 88,24\% dengan mengunakan model Auditory, Intellectually, Repetition (AIR) (Astuti, 2018). Kedua penelitian tersebut menunjukan bahwa model pembelajran inovatif dan kooperatif dapat meningkatkan keterampilan pemecahan masalah. Oleh sebab itu, peneliti menerapkan model pembelajaran Think Talk Write (TTW) dimana tujuan dari model ini untuk menumbuhkan keterampilan pemahamaman peserta didik serta komunikasi matematika (Yamin \& Ansari, 2008).

Think Talk Write (TTW) merupakan model yang dimulai dengan cara menyimak, menganalisis/mengkritisi, dan mencari pemecahan masalah dengan membuat kalimat bermakna (Hamdayama, 2014; Ngalimun, 2014). Pesrta didik dilibatkan langsung dalam pemecahan masalah. Sehingga model ini cocok digunakan untuk mengatasi 
masalah yang dihadapi. Sintaks pada model pembelajaran TTW yaitu think (mencatat kalimat matematika dari hasil bacaan), talk (berdiskusi berdasarkan hasil catatan), write (merumuskan jawaban dari hasil diskusi), dan presentasi (Hamdayama, 2014).

Berpijak dari beberapa hal di atas, melalui diskusi antara peneliti dan guru maka tujuan penelitian ini untuk meningkatkan keterampilan pemecahan masalah interpretasi data pada soal cerita diterapkan model pembelajaran model Think Talk Write (TTW) yang dapat mengatasi kendala yang dihadapi.

\section{METODE}

Penelitian dilakukan di SD N Geneng I Sukoharjo dengan pendekatan kualitatif serta jenis penelitian Penelitian Tindakan Kelas (PTK). Peserta didik yang berjumlah tiga belas serta seorang guru kelas $\mathrm{V}$ merupakan sumber data yang diteliti. Teknik pengumpulan data dari penelitian ini terdiri dari wawancara, observasi kinerja guru dan aktivitas peserta didik, tes keterampilan pemecahan masalah dan dokumentasi. Validasi data yang dipakai menggunakan triangulasi teknik serta triangulasi sumber. Setelah penelitian terlaksana, data dianalisi menggunakan analisis interaktif Miles dan Hubermen. Keberlangsungan PTK ini selama tiga siklus, dengan satu pertemuan dalam keberjalanan tiap siklus.

Pedoman penilaian keterampilan pemecahan masalah interpretasi data dikategorikan berdasarkan pendapat ahli sebagai berikut (Arikunto dan Jabar, 2010).

Tabel 1. Kategorisasi Penilaian Keterampilan Pemecahan Masalah Interpretasi Data

\begin{tabular}{cc}
\hline Rentang Nilai & Kategori \\
\hline $86-100$ & Sangat Terampil \\
$70-85$ & Terampil \\
$46-69$ & Cukup Terampil \\
$30-45$ & Kurang terampil \\
$\leq 29$ & Tidak Terampil \\
\hline
\end{tabular}

Tabel 1 menujukan bahwa peserta didik memperoleh nilai $\geq 70$ sudah dikategorikan terampil. Indikator kinerja penelitian pada penelitian ini yaitu $\geq 80 \%$ diukur dari hasil tes keterampilan pemecahan masalah interpretasi data, dihitung dari jumlah peserta didik yang meraih kategori terampil atau memenuhi nilai $\geq 70$.

\section{HASIL DAN PEMBAHASAN}

Usaha untuk meningkatkan keterampilan pemecahan masalah peserta didik kelas V SD N Geneng I melalui penerapan model pembelajaran Think Talk Write dilaksanakan dengan tiga siklus. Langkah-langkah pokok penerapan model pada penelitian sebagai berikut: a), berkelompok (b), mencari informasi (think) (c), berinteraksi dan berkolaborasi (talk) (d) mengkontruksikan hasil pengetahuan (write).

Nilai keterampilan pemecahan masalah interpretasi data diperoleh dari rata-rata pencapaian empat aspek penilaian keterampilan pemecahan masalah pada saat melaksanakan evaluasi berupa soal cerita, meliputi: a), memahami masalah (b), merencanakan penyelesaian (c), menjalankan rencana (d), pemeriksaan kembali.

Peningkatan pemecahan masalah interpretasi data melalui model Think Talk Write pada peserta didik kelas $\mathrm{V}$ dinyatakan berhasil. Peningkatan nilai tes keterampilan dapat dilihat pada tabel berikut:

Tabel 2. Distribusi Nilai pada Penelitian

\begin{tabular}{lcc}
\hline \multicolumn{1}{c}{ Siklus } & Rerata & Ketuntasan Klasikal \\
\hline Pratindakan & 56,42 & $30,77 \%$ \\
Siklus I & 66,69 & $46,15 \%$ \\
Siklus II & 75,23 & $69,23 \%$ \\
Siklus III & 82,69 & $84,23 \%$ \\
\hline
\end{tabular}


Volume 9 Nomor 1 Tahun 2021

Berdasarkan tabel 2 dapat disimpulkan bahwa rerata dan ketuntasan klasikal selalu mengalami kenaikan pada setiap siklusnya. Rerata pada pratindaakan sebesar 56,42 lalu meningkat pada siklus I menjadi 66,69. Pada siklus II menjadi 75,23 dan meningkat menjadi 82,69 pada siklus III. Sedangkan untuk ketuntasan klasikal pada pratindakan sebesar 30,77\% lalu meningkat pada siklus I menjadi 46,15\%. Pada siklus II menjadi $69,23 \%$ dan menjadi $84,23 \%$ pada siklus III. Ketuntasan klasikal pada siklus I ke siklus II mengalami peningkatan tertinggi sebesar $23,08 \%$ diatas rerata kenaikan setiap siklus sebesar $17,82 \%$. Hal ini dipengaruhi perbaikan pada perbaiakan alokasi waktu serta pembagian kelompok yang lebih kecil untuk keefektifan pada poin talk(berdiskusi). Dimana faktor tutor teman sebaya lebih efektif dan efesien jika dilaksakan pada kelompok kecil. Peserta didik menjadi lebih fokus dan mengurangi bercada keitka kelompok besar. Untuk peningkatan aspek dapat dilihat pada tabel berikut:

Tabel 3. Perbandingan rerata antar aspek keterampilan pemecahan masalah

\begin{tabular}{lccc}
\hline \multicolumn{1}{c}{ Aspek } & Siklus I & Siklus II & Siklus III \\
\hline Memahami masalah & 65,42 & 76,00 & 86,19 \\
Merencanakan penyelesaian & 70,42 & 75,27 & 82,58 \\
Mejalankan rencana & 65,31 & 73,27 & 82,58 \\
Pemeriksaan kembali & 63,58 & 70,97 & 82,58 \\
\hline
\end{tabular}

Tabel 3 menunjukan bahwa setiap aspek pada keterangan diatas menujukan hasil positif dan meningkat pada setiap siklus. Hal ini dibuktikan dengan indikator setap aspek, pada aspek memahami masalah pada pertemuan pertama siklus I memiliki rerata 65,42 meningkat pada siklus II dengan rerata sebesar 76,00 dan meningkat pada siklus III menjadi 86,19. Aspek merencanakan penyelesaian pada pertemuan pertama siklus I memiliki rerata 70,42 meningkat pada siklus II dengan rerata sebesar 75,27 dan meningkat pada siklus III menjadi 82,58. Aspek menjalankan rencana pada pertemuan pertama siklus I memiliki rerata 65,31 meningkat pada siklus II dengan rerata sebesar 73,27 dan meningkat pada siklus III menjadi 82,58. Aspek pemeriksaan kembali dan hasil pemecahan masalah pada pertemuan pertama siklus I memiliki rerata 63,58 meningkat pada siklus II dengan rerata sebesar 70,97 dan meningkat pada siklus III menjadi 82,58 . Setiap aspek dalam penelitian ini selalu mengalami peningkatan rerata. Rerata terbesar diperoleh dalam memahami masalah, dikarenakan untuk memahami masalah tidak mengunkan perhitungan sama sekali yang diperlukan adalah ketelitian menuliskan semua informasi yang ada dari soal cerita. Soal cerita menyajikan tulisan-tulisan yang mepunyai nilai serta perlunya pemahaman dengan menyelidiki setiap kata yang bermakna. Menurut Sumawarni (2014: 1), karakter soal cerita sebagai teks serta pemakaian bahasa yang khas merupakan fator kunci kegagalan pemahaman peserta didik. Sehingga, diperlukan cara untuk meningkatakan pemahaman kata yang khas dalam soal matematika. Pemahaman kata yang khas dapat diatasi dengan model pada tahap think. Dimana peserta didik membaca teks dan membuat cataatan dari pemahaman hasil bacaan secara individu untuk didiskusikan secara berkelompok (Yamin \& Ansari, 2008). Pada aspek merencanakan peyelesaian, menjalankan rencana dan pemeriksaan kembali kenaikan rerata tidak lebih tinggi dari memahami maslah. Hal ini dikarenakan ketiga aspek berkaitan dengan perhitungan matematika. Dimana terdapat kendala-kendala: Peserta didik cenderung menghafal "kata kunci" untuk digunakan dalam rumus/formula, Kuranya minat peserta didik dalam pemecahan masalah matematika karena urutannya panjang serta rumit yang membuat motivasi luntur, Kurangnya imajinasi dan pengalaman peserta didik dalam pemahaman bagian atau keseluruhan dari teks bacaan untuk pertimbangan masalah yang dihadapi (Phonapichat et al., 2014). Untuk mengatasi faktor perhitungan 
diatasi dengan tahap talk dan write. Talk dimana peserta didik berkolaborasi dan berinteraksi dengan teman untuk membahas catatan yang dibuat, sedangkan write mengkontruksi hasil pengetahuan sebagai hasil kolaborasi dan menuliskannya dalam lembar jawab untuk pemecahan masalah yang dihadapi (Yamin \& Ansari, 2008).

. Penelitian Tindakan Kelas (PTK) ini mencapai ketuntasan klasikal sebesar $84,23 \%$. Penelitian ini sejalan dengan penelitian yang dilakukan Veramita yang menggunakan model TTW untuk peningkatan keterampilan pemecahan masalah dengan perbedaan pada materi yang diambil, hasil penelitian ini peserta didik mecapai 90\% dalam ketuntasan klasikal (Vermamita \& Mulyono, 2018). Lusiana juga melakukan penelitian tentang pemecahan masalah dengan hasil ketuntasan klasikal sebesar 95,83\% dari seluruh peserta didik (Novita \& Matsuri, 2018).

\section{SIMPULAN}

Berlandaskan hasil penelitian pada siklus I, II dan III terjadi peningkatan pemecahan masalah interpretasi data melalui model pembelajaran Think Talk Write (TTW) pada peserta didik kelas V SD N Geneng I tahun ajaran 2020/2021. Peningkatan dibuktikan dengan ketuntasan klasikal dari pratindakan sampai siklus III. Peningkatan juga terjadi pada setiap aspek pemecahan masalah.

Model TTW dapat digunakan dalam proses pemecahan masalah, karena proses pemecahan masalah serta sintak model memiliki alur yang sesuai. Pertama peserta didik diminta berpikir (analis, pemecahan masalah, mencari solusi) dengan membaca. Kemudian mencatat hasil pemikiran dan mengkomunikasikan dengan teman kelompok, lalu menulis/mencari jawaban dari teks bacaan. Akhir dari proses pemecahan masalah dan model adalah sama-sama menuliskan solusi atau pendapat dengan tulisan. D'Angelo \& West (2000), menyatakan salah satu cara pemecahan masalah dengan menuliskan kalimat yang menjelaskan pendapat. Pemakaian tulisan secara independen menunjukkan bahwa tugas menulis dapat meningkatkan kemampuan peserta didik untuk menggambarkan pemikiran di balik proses solusi mereka ketika terlibat dalam pemecahan masalah matematika (Petersen et al., 2017)

Penelitian ini memberikan implikasi teoritis yang mana dapat dijadikan referensi bagi penelitian sejenis. Sedangkan untuk implikasi praktis berupa peningkatan keterampilan pemecahan masalah mengunakan model Think Talk Write (TTW) dalam mata pelajaran Matematika. Ataupun bisa dikembangkan lagi pada mata pelajaran lainya.

\section{DAFTAR PUSTAKA}

Astuti, W. D. (2018). Peningkatan Keterampilan Menulis Aksara Jawa Melalui Model Pembelajaran Kooperatif Tipe Think Talk Write (TTW) Berbantu Media Flannelgraph. Universita Sebelas Maret.

D'Angelo, J. P., \& West, D. B. (2000). Mathematical Thinking Problem-Solve and Proofs. United States of America: PEARSON Prentice Hall.

Hamdayama, J. (2014). Model dan Metode Pembelajaran Kreatif dan Berkarakter. Bogor: Ghalia Indonesia.

Kallick, B., \& Brewer, R. (1997). How to Assess Problem-Solving Skills in Math. United States of America: SCHOLASTIC.

Ngalimun. (2014). Strategi dan Model pembelajaran. Yogyakarta: Aswaja Pressindo.

Novita, L., \& Matsuri. (2018). Peningkatan Kemampuan Pemecahan Masalah Soal Cerita Operasi Hitung Campuran melalui Model pembelajaran Assurance, Relevance, Interest, Assesment, Satifaction (ARIAS) pada siswa kelas IIIA Sekolah Dasar. Didaktika Dwija Indria, 6(4).

Petersen, B., Mcauliffe, S., \& Vermeulen, C. (2017). Writing and mathematical problem solving in Grade 3. South African Journal of Childhood Education, 7(1), 483. https://doi.org/10.4102/sajce 
Phonapichat, P., Wongwanich, S., \& Sujiva, S. (2014). An Analysis of Elementary School Students' Difficulties in Mathematical Problem Solving. Procedia - Social and Behavioral Sciences, 116(2012), 3169-3174. https://doi.org/10.1016/j.sbspro.2014.01.728

Rahmawati, I. (2016). Penerapan Strategi Pembelajaran Think Talk WRITE (TTW) untuk Meningkatkan Keterampilan Menulis Puisi. Didaktika Dwija Indria, 4(449), $1-7$.

Sanjaya, W. (2008). Pembelajaran Dalam Implementasi Kurikulum Berbasis Kompetensi. Jakarta: Prenada Media Group.

Stevens, M. (1997). How to Be a Better Problem Solver. London: Kogan Page.

Sukmadinata, N. S., \& Syaodih, E. (2012). Kurikulum dan Pembelajaran Kompetensi. Bandung: PT Refika Aditama.

Sumawarni. (2014). Panduan Penyusunan Soal Cerita Matematika untuk Guru Sekolah Dasar. Surakarta: UNS Press.

Surya, A., Marmoah, S., \& Istiyati, S. (2018). Learning trajectory to improve students ' critical thinking skill in graphing and statistics concept at elementary education Learning Trajectory to Improve Students ' Critical Thinking Skill in Graphing and Statistics Concept at Elementary Education. AIP Conference Proceedings, 020091(September), 1-6. https://doi.org/10.1063/1.5054495

Vermamita, I. D., \& Mulyono, H. (2018). Improving Mathematical Problem Skill Though The Application Cooperative Learning Model of Think Talk Write (TTW) Type in Student Grade V Elemntary Shool. Soc. Humanit. Edu. Stud, 1(1), 360-366.

Winarni, E. S., \& Harmini, S. (2015). Matematika untuk PGSD. Bandung: Remaja Roskadakarya.

Yamin, M., \& Ansari, B. I. (2008). Taktik Mengembangkan Kemampuan Individu Siswa. Jakarta: Gaung Persada Press. 